\title{
Reportaje al pie de la escena
}

\section{Víctor Reyna}

Jerzy Grotowsky sacudió al mundo con su teatro pobre cuando presentó, en los años 60 del siglo pasado, el manifiesto de un estilo de transición ${ }^{1}$ que proponía lecturas enfáticas en torno a dos elementos esenciales: actor y público. Al maestro polaco le interesaba descubrir al actor como un todo aunque para ello fuera necesario la construcción de una poética performativa particular, a partir de un método científico en el que cuerpo, voz y psiquis llegaran a alcanzar el máximo de armonía estética dentro de un fenómeno teatral en el que el espectador permanece como testigo activo, capaz de presenciar y no olvidar.

Con su inusual desapego al texto, Grotowsky libera al teatro de la "matriz literaria." Desarrolla fuertes y constantes experimentos para fortalecer la capacidad comunicativa del intérprete y su expresión física, así como persigue intensificar los vínculos entre actor y espectador, una de las corrientes más activas del laboratorio de Wroclaw. ${ }^{2}$ Contrariamente a lo que se conoce estos preceptos son mucho más trascendentes que la simpleza de una escena desnuda, a lo que popularmente se ha reducido la referencia de teatro pobre. Idea que erróneamente deja de lado la indagación antropológica. Búsqueda dirigida a la expresión original, empeñada en cristalizar la comunicación espectacular por medio de resortes ancestrales. Es por ello que el actor, para Grotowsky, está en el centro de la escena y no precisamente porque se haya despoblado de lo demás. Sino porque ese actor, poblado y edificado desde el interior representa el elemento más rico y maleable del espectáculo sin retóricas de ninguna índole.

Consciente de la herencia grotowskiana Rubén Pagura estructura un homenaje a Julius Fucik, basado en el testimonio que el dramaturgo y periodista checo escribiera durante sus últimos días. Reportaje al pie de la horca sirve de comodín para articular un discurso teatral comprometido con 
la esencia más genuina del individuo y su derecho a la libertad de expresión y pensamiento, más allá de cualquier apego ideológico.

Uno de los elementos más sobresalientes en la puesta, que también dirige el propio Pagura, es el intento de estimular esas reacciones humanas primitivas en el actor que tanto sedujeron al maestro polaco. Hacia ese actor convertido en todo teatral, sin auxilio de los consabidos bienes parafernales, hasta alcanzar la expresión plena, sin cortapisas ni bloqueos, se dirige la revalorización del estudiado sistema psico-físico. Grotowsky es el artesano de la técnica inductiva. Su contraposición a la acumulación de habilidades del actuante le llevó a provocar una revelación/revelación del actor contra sí mismo en aras de restaurar sus impulsos naturales. Cuando asistimos a la propuesta de Julius disfrutamos, de alguna manera, un espectáculo cargado de este tipo de premisas, donde las artes expresivas del actor facilitan la fluidez de un conjunto de gestos, sonidos, movimientos, en ocasiones más cercanos a un ritual primitivo que a un ejercicio contemporáneo de actuación. Aunque también conocemos que lo contemporáneo suele ser contradictoriamente primitivo porque lo que más nos llama la atención es la recuperación de lo arcaico.

El texto de Julius avanza al servicio del actor-director y el público articulando un proceso de identificación ideológica en el que interviene la conciencia del intérprete y la metaconciencia del personaje. Es decir, un proceso de pre-concientización estética del personaje a través de la mirada objetiva de los encargados de componer la puesta en escena. Cuando Julius se convierte en personaje teatral, ya había sido mitificado. Y Julius, como personaje-mito, alcanza una dimensión metalingüística en escena cuando al convertirse en vehículo de confrontación entre el actor, puesta y público, suceso que el texto original o la versión dramatúrgica no provocarían por si solos.

En el espectáculo unipersonal de Rubén Pagura reina el cuerpo del actor. Inmerso en un profundo ciclorama negro y con una pequeña pantalla de cine tensada por cuatro puntos, el centro de la escena se convierte en una monumental rosa de los vientos. Allí gravita la escena alrededor de puntos cardinales dictados por el actor por medio de la excelencia de sus recursos expresivos. Cartografía teatral que completa una silla ordinaria en torno a la que el actor gira teatralmente y mientras derrama su provocación histriónica recibe el bombardeo de las luces.

El complemento de la magra utilería es, sin dudas, el cuerpo simbolizante y virtuoso, las sombras, la voz y la fragmentación de códigos teatrales 


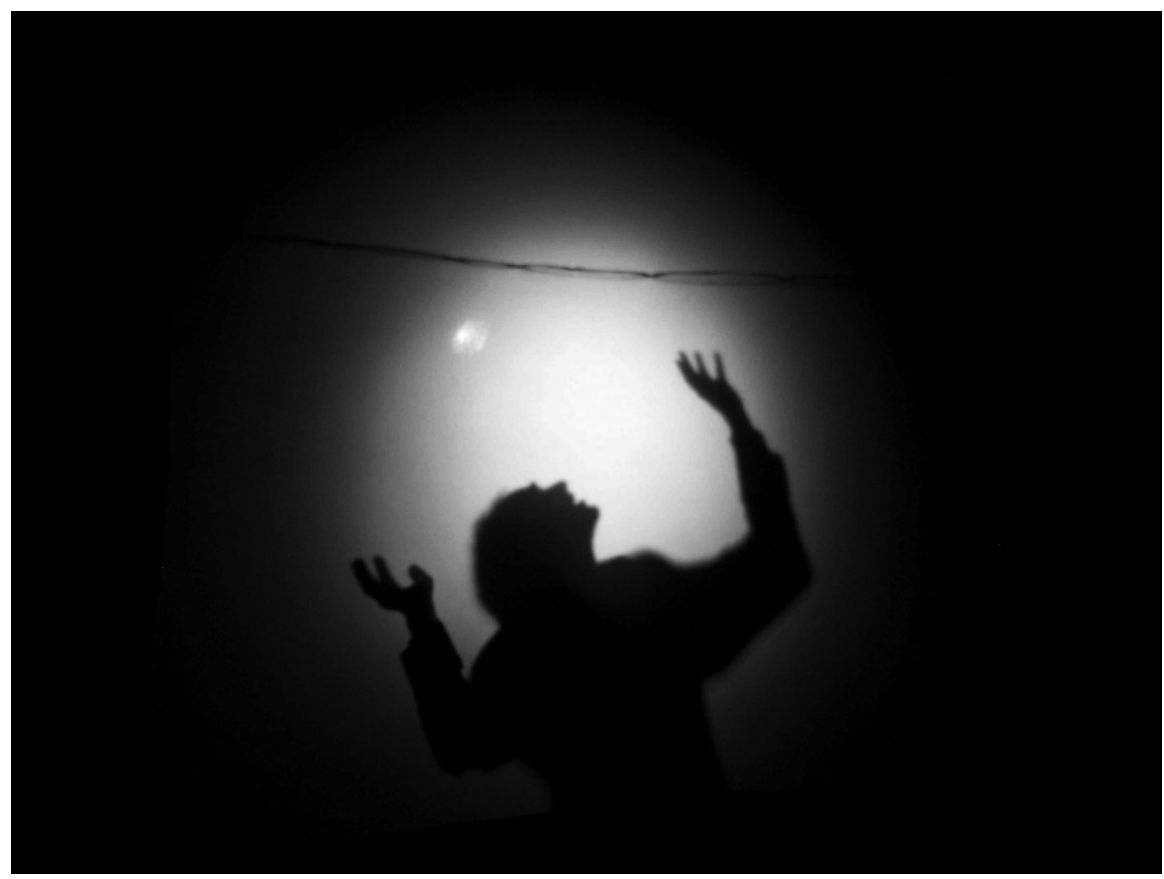

Julius. Foto: Víctor Reyna

que alcanza relevancia en el montaje como la creación de zonas espaciotemporales delante y detrás de la pantalla estática. Conjunto de elementos que facilitan la recontextualizacion del texto original de Fucik.

El juego consciente con las sombras, que alcanza alto valor dramática, está estrechamente relacionado con otro de los postulados del maestro polaco, a veces olvidado, en ocasiones retomado. Con Grotowsky se altera la relación habitual actor-espectador y para él uno de los elementos de importancia en la creación del espacio de representación era la búsqueda de ese lado infantil, primitivo, especie de regresión a los orígenes, que le permitirá tanto al actuante como al intérprete (el público) responder espontáneamente y sin prejuicios socioculturales, ante el fenómeno de la escena.

La animación de la palabra inanimada se convierte en un recurso fundamental para el maestro polaco y alcanza un acabado virtuoso en el trabajo actoral de Julius. Pagura es un prestidigitador de la palabra. No es tan importante lo que se dice sino como se dice. Y la animación de la palabra, en ocasiones se refuerza con la animación del espacio, en un juego tridimensional de prestaciones del cuerpo, donde se está cercano a alcanzar 
el nivel ritual dentro de la escena. Escena que, de manera inefable, codifica conexiones ditirámbicas, veladas por esa pantalla de cine que, lejos de recibir pasivamente, proyecta, como una vía de doble sentido referencial.

A la edad de ocho años tuve ocasión de encontrarme con el texto del periodista y dramaturgo checo en la "Biblioteca Espontánea" de la escuela primaria donde cursaba los primeros grados en el arte. Entre Chaplin, Verne y Fucik transcurrieron largas horas de lectura individual. Pero siempre tuve muy presente la cabellera negra de aquel Julius, tan lejano e intangible, que permaneció en mi mente a lo largo de muchos años y que aun hoy me resisto a olvidar.

Confieso que el encuentro con el pelo argentado del actor (Rubén Pagura) provocó en mí una pequeña conmoción. No era esa la caracterización que esperaba. Decididamente me había dejado arrastras por una convención. Pensé entrar en contacto con un actor caracterizado y rejuvenecido. Sin embargo pronto comprendí que el espectáculo no persigue sino todo lo contrario, es decir, desnudar el interior del ser humano (léase actor/espectador) por medio de la ceremonia teatral.

La intensidad de la voz, las energías dominadas y el vibrante intercambio del intérprete con el público, poco a poco fue desdibujando la imagen grabada en mi memoria. Y a medida que el espectáculo transcurría me identificaba más y más con el sistema de signos del cuerpo mimetizado del intérprete. Simbolizante perfecto para alcanzar la psique colectiva a pesar del color de su pelo.

Nos enfrentamos a un texto que nació sin ser dramático y que el propio intérprete, en su doble condición de actor/director, dramatiza mediante una versión erudita. El valor trascendente de las páginas de Fucik embarga el espacio cerrado de la representación, sórdido y deshumanizado, en cuanto a color y forma, en contraste con la serenidad del profundo humanismo de su contenido.

En otras palabras, la controversia interior versus exterior, hacia donde apunta toda la reflexión grotowskiana, se evidencia en la obra. Praga se rinde a nuestros pies por medio del actor. Sus puentes y callejuelas estrechas aparecen y se desvanecen a través de la coloratura, las transiciones y el desarrollo de la acción que todos sabemos termina en tragedia, ${ }^{3}$ pero que el actuante logra elevar a categoría de mito, cuando brazos, piernas, tronco y expresión se proyectan más allá del escenario, del aquí y el ahora.

El actor doma con serenidad la nada teatral, proveniente de esa superficialmente entendida pobreza grotowskiana. Y constantemente logra un 
exquisito transformarse mediante la activación de experiencias sensoriales que tienen su punto de partida en la concepción nemotécnica de la mise en scene.

Pero Julius no es una obra publicotropista. Lo cual representa una verdad de Perogrullo. Se advierte en el discurso teatral la negación a provocar la aceptación y el elogio fácil del público. El espectáculo huye de fórmulas clásicas porque se trata de un producto artístico confrontativo. El actor tiende hacia la maestría técnica en la misma medida que el espectáculo intenta rescatar la simbiosis original de la creación artística en la que ritual y arte estaban interconectados para provocar reacciones genuinas.

Si bien el propio Pagura reconoce, en la anatomía del espectáculo, rasgos del legado de Eugenio Barba y Peter Brooks, ${ }^{4}$ no es menos cierto que la esencia grotowskiana prevalece por encima de las demás como espina dorsal del espectáculo. El protagonismo del actor, la importancia de la expresión física, la animación de la palabra y el debate con el público no pretenden ilustrar un texto sino proponer una vía de evacuación de respuestas, esas que provienen del respetable ${ }^{5}$ y que puede estimular el simbolismo activo del intérprete, cuyo indiscutible precursor no es sino el director de El Teatro de las 13 Filas. $^{6}$

Fucik muere físicamente para trascender en su texto. El apetito de inmortalidad de Fucik cristaliza en la ceremonia ritual-teatral de Julius. Cuerpo, voz y energías del actor pavimentan un pasaje de recordación a las víctimas del holocausto, reflexión sobre la esencia del ser humano y alrededor de las posibles dimensiones de la vida más allá de la vida, episodio que atormenta por igual a público y artistas.

Pagura interpreta con su cabello argentado a un Julius Fucik detenido en el tiempo y nos remite a un teatro desnudo, despoblado y pobre. ${ }^{7}$ De una pobreza contradictoria donde la única riqueza posible es la capacidad histriónica del intérprete en busca de la excelencia interpretativa en ese viaje en busca de la verdad que ha tenido varias estaciones: Opole, Wroclaw, Pontedera. ${ }^{8}$ La verdad contradictoria del ser humano, que de tan moderno continúa siendo tan arcaico.

San José, 25 de julio del 2009 


\section{Notas}

1 Al decir de Eugenio Barba, quien con el tiempo se convertiría en uno de los más grandes exponentes de los postulados growtoskianos y en cierta medida uno de los discípulos más avanzados del maestro, cuando propone una manera muy particular de enfocar el fenómeno del arte escénico en el que el actor continúa el viaje a los orígenes antropológicos y se encuentra con la esencia de su expresión artística.

2 Durante los años 60, Grotowsky se refugia en Wroclaw para desarrollar sus experimentos teatrales y desde allí desafía al resto del mundo con su peculiar visión del espectáculo, el actor y el espectador.

3 No por gusto Julius Fucik desaparece al final de la obra abandonando la escena a la que no regresa ni para recibir los aplausos del público. La lectura en este caso es muy clara, el personaje, el héroe, el hombre nos dejó el legado de la palabra tras su desaparición física.

${ }^{4}$ Peter Brooks ha dedicado gran parte de su trabajo artístico a explorar sobre la poética teatral de Jerzy Grotowsky y es uno de sus continuadores.

5 ....respetable público...

6 Jerzy Grotowsky desarrolló su labor de dirección y experimentación teatral durante varios años en la sala del mismo nombre.

7 Alejado de la retórica teatral Grotowsky perfila su concepto de teatro pobre sin el lastre del teatro aristotélico opuesto radicalmente a la épica teatral de Bertold Brecht.

8 El laboratorio teatral de Grotowsky estuvo radicado en varias ciudades: hasta 1965 en Opole, de donde se trasladó a Wroclaw para terminar en Pontedera, la Toscana italiana, donde murió de una enfermedad, según dicen los periódicos, "no precisada." 